\title{
Erläuterung zur Schreibweise russischer und jiddischer Wörter
}

Russische Begriffe, Persönlichkeiten und Städtenamen in kyrillischer Schrift werden der Normierung DIN 1460 folgend in lateinischen Buchstaben transliteriert. Zum Beispiel: толчок (tolčok), иосиф сталин (Iosif Stalin) oder куйбышев (Kujbyšev).

Bei der Transliteration aus dem Jiddischen folge ich der in der englischen Sprache verbreiteten Variante, wie sie vom YIVO vorgeschlagen wurde. Zum Beispiel: יצחק פערלאָוו (Yitskhok Perlov).

Ausländische Städtenamen, deren deutsche Schreibweise in der deutschsprachigen Historiografie verbreitet ist, werden nicht transliteriert. Zum Beispiel: Warschau, Moskau, Lemberg oder Taschkent.

In direkten Zitaten wurden die jeweiligen Schreibweisen der Autorinnen und Autoren unverändert übernommen. 
